Reda Poneliené

https://doi.org/10.26881/pwe.2018.42.14

ORCID: 0000-0003-0077-3321

Šiauliai University

rponeliene@gmail.com

Asta Širiakoviene

ORCID: 0000-0002-7444-8612

Šiauliai University

sasta23@gmail.com

\title{
Preschool-age children's education by art: problems and possibilities
}

\begin{abstract}
Summary
In the preschool age, one of children's favourite activities is drawing, playing with colours, shapes, various techniques. The empirical study conducted in March, $2018(\mathrm{~N}=182)$ demonstrated that respondents evaluated preschoolers' education by art as significant for children's educational achievements, self-development of value approaches and abilities. The teachers who participated in the research disclosed the possibilities provided by art in the educational process and pointed out the problems that hindered appropriate organization of art activities for preschoolers.
\end{abstract}

Keywords: art, preschool age, the teacher's role, children's education

\section{Introduction}

The child's artistic expression is the expression of the child's experienced impressions, experiences, understanding, emotions and feelings and their representation by means of artistic expression: action, movement, word, voice intonation, colour, line, shape, etc. It includes music, dance, performing and visual expression (The Description of the Achievements of the Preschool Age Children, 2014). Children whose visual expression is rich, spontaneous, open, sincere, full of emotions, creativity and ingenuity create original, expressive, decorative pieces of art, reveal the individuality of their visual expression and creation, their peculiar style, and willingly, gladly undertake visual creation, share the acquired experience with others, are observant to the details of art, objects of the environment and events, listen more intently, study it more thoroughly by other senses and distinctively disclose acquired experiences in visual creation (Methodological Recommendations for Preschool Education, 2015).

In childhood, drawing is a natural way of learning about the world. It is one of the early forms of communication and thinking like a game or language (Brazauskaite 2003). Most of the preschool-age children like drawing and they widely apply this, seeking various goals while playing or in other daily activities at home and the preschool education institution 
(Hall, 2009). According to S. Wright (2007), drawing provides children with the opportunity to create, share, convey meaning, using verbal and non-verbal ways. Spontaneous pictorial activity is the most natural and interesting for the child, it does not require exceptional will or intellectual efforts. According to D.M. Foster et al. (2013: 1), preschoolers learn that personal expressions expressed during the art process are valuable. $<\ldots>$ Children realize that the uniqueness and value of their artworks is self-expression. In addition, children use drawing to develop, create, communicate and record their thoughts, drawing has a great impact on children's communication and their development as a whole (Ring 2001).

The process of art is very important and beneficial for children from many standpoints. The results - pieces of art - are also very valuable for understanding the success or disorders of children's development (Adomaitienè 2016). V. Židonyte (2005) notes that the teacher should not interfere in the child's creative process; i.e., it is necessary to allow the child to freely create, draw, provide more self-expression opportunities for the child, which will result in greater creativity, and his / her artworks will be original, free and unrestrained. On the other hand, the task raised for the teacher is to develop the child's need to draw and develop his / her hand, vision and thinking in order to fulfil that need: the child needs a sensitive teacher who assesses his / her abilities, interests, questions, ideas, initiates appropriate development of skills, the use of materials (McClure et al. 2017).

The research aim is to analyze problems and possibilities of the preschool-age children's ( $4-5$ years old) education by art.

\section{Research tasks:}

1. To find out the possibilities of children's education by art and its importance for children's self-educational achievements, self-development of value approaches and abilities.

2. To disclose the teacher's role while planning and organizing art activities and assessing learners' achievements in the areas of artistic expression and creativity.

3. To distinguish problem areas of organizing education by art and foresee improvement perspectives.

\section{Research Methodology}

The research problem can be outlined by the questions:

1. What are the possibilities of preschool-age children's education by art?

2. What is the preschool education teacher's role in the process of education by art?

3. What problems are encountered organizing children's education by art?

The study was conducted in March, 2018.

\section{The research instrument}

The research instrument was developed by the authors of the study. The questionnaire for teachers consisted of an instructional-motivational part, demographic (social characteristics of the respondents) and diagnostic blocks. The instructional-motivational part 
includes the research aim, the instruction how to fill in the questionnaire, the example of marking, the guarantee of the respondents' anonymity. The demographic block consists of nominal scales: the teachers' gender, education, and qualification category. Diagnostic blocks were constructed considering problem questions of the research. The questionnaire includes open-ended and closed-ended questions. Summarizing the research data, the respondents' answers to open-ended questions are used as supplementary, illustrating the statistical information. The respondents' exact statements are given by citing them.

\section{Data analysis}

Empirical data were analysed using the Microsoft Excel 2010. Descriptive statistical methods were employed for calculating numerical characteristics of the indicators (frequency of data distribution, in percent). The analysis of answers to open-ended questions was carried out using the content analysis method. The respondents' answers were read several times and grouped into separate groups according to the content of answers. Presenting the generalized results of the research, they are compared with the results of similar / analogous studies conducted by Lithuanian and foreign scientists.

\section{The respondents' characteristics}

The study involved 182 teachers of preschool education institutions working with 4-5 year old children. All respondents were women whose pedagogical work seniority ranges from 5 to 31 years and over. 39.2 percent of the research participants have the qualification category a senior educator; 35.7 percent - an educator; $25.1 \%$ - an educator methodologist. 72.5 percent of the teachers who participated in the research work in preschool education institutions of cities; the remaining part - in nurseries of districts. Although the research sample does not allow to make broad generalizations, the results obtained enable to preliminarily distinguish the problems and possibilities of education by art and formulate guidelines for other studies.

\section{Possibilities of children's education by art at the preschool education institution}

\section{Better self-educational achievements of children}

The teachers who participated in the research were asked what children's self-educational achievement areas were mostly influenced by education by art. According to the respondents, education by art mostly influences the child's creativity (17.6 percent), imagination (16.4 percent) and self-expression (15.4 percent). The teachers' attitude coincides with the position of the researchers W.E. Eisner (2002), M.A. Kindler (2010), V. Vecchi (2010) et al. that in the art activities, children develop their creative potentials by using different materials and techniques; they develop visual-spatial intelligence, visual sensitivity, imagination, aesthetic perception and specific art-expressive possibilities as well as with the approach outlined in The Description of the Achievements of the Preschool Age Children (2014) that the child's good self-educational achievements in the areas of aesthetic 
perception and artistic expression enrich the world of the child's imagination and emotions, develop self-expression and creative activity possibilities, help the child to unfold his / her individuality, uniqueness.

\section{Development of fine motor skills}

Preschool education teachers (14.3 percent) who participated in the research state that during art classes, children's fine motor skills are developed. Art activities provide great possibilities for this. Analogous findings are presented by K. Hille et al. (2015), who note that preschool age is important time for the development of fine motor skills. In addition, drawing is used for developing the writing skills of children (Einarsdottira et al. 2009), which is important preparing for a successful start at school.

\section{Integrated education}

Research participants agreed that art mostly helps to develop children's artistic competency, but it can also be integrated into various group activity areas. Some of them (12.1 percent) provided illustrative examples of the statements (Table 1).

Table 1. Development of preschoolers' competencies by integrating art in the educational process

\begin{tabular}{|l|c|l|}
\hline $\begin{array}{c}\text { Competency } \\
\text { developed }\end{array}$ & $\begin{array}{c}\text { No. of } \\
\text { answers }\end{array}$ & \multicolumn{1}{c|}{ More characteristic examples } \\
\hline $\begin{array}{l}\text { Cognitive } \\
\text { competency }\end{array}$ & 11 & $\begin{array}{l}\text { "Drawn impressions from the excursion"; "A certain number of } \\
\text { items are drawn"; "Applique, drawings according to the topics } \\
\text { Animals, Birds". }\end{array}$ \\
\hline $\begin{array}{l}\text { Communicative } \\
\text { competency }\end{array}$ & 11 & $\begin{array}{l}\text { "After listening to the text, illustrations are drawn"; "A read tale } \\
\text { is illustrated"; "Books are created". }\end{array}$ \\
\hline Social competency & 4 & $\begin{array}{l}\text { "Art is integrated discussing such topics as My Family, } \\
\text { Professions". }\end{array}$ \\
\hline $\begin{array}{l}\text { Health protection } \\
\text { competency }\end{array}$ & 7 & $\begin{array}{l}\text { "Inventory, equipment of various colours are used in physical } \\
\text { education classes", "Various colour balls, hula hoops both in the } \\
\text { gym and outdoors, are used". }\end{array}$ \\
\hline
\end{tabular}

To sum up, it can be stated that art mostly helps to develop artistic competency, while integration of art activities into other activity areas helps to develop other competencies of pre-schoolers, too.

\section{Development of value approaches and basic abilities}

According to most teachers, it is important to seek that children should feel the joy provided by art expression (82.4 percent), enjoy their own and other children's creative work (79.1 percent), spontaneously and distinctively express their feelings, impressions, thoughts and emotions (78.5 percent), take interest in and admire the environment and works of art (75.3 percent). The research results demonstrate that the respondents perceive the importance of art for preschool-age children's education and it is likely that during activities develop the said value approaches and basic abilities. 


\section{The teacher's role in the process of education by art}

\section{Individualization ${ }^{1}$ of the curriculum}

The Description of the Achievements of the Preschool Age Children (2014) states that educators have to improve the availability of the curriculum for each child, individualize the curriculum, process and teaching aids and to seek targeted maximum progress of each child's self-education according to his / her powers. According to G. Gronlund (2015), we can speak about successful results of children's education when children reach their potential. Such education requires individualization. Having analysed the research results, it turned out that in the opinion of more than half ( 56 percent) of the teachers who participated in the research, individualisation of art activities was necessary. The respondents state that while individualising artistic activities "creativity is revealed more", "children unfold, communicate, express their thought, idea more sincerely", "concentrate better, do not disturb others and themselves", "are more self-confident", etc.

A small share (12.1 percent) of preschool education teachers who participated in the research believes that individualization of art activities is unnecessary, as every learner creates, draws, colours the way he / she can. In addition, working in groups, children learn from each other: "If six children are sitting at the table, their drawings are the same, one of them starts and others copy...", "< ... this way children learn from one another".

Thus, individualization of education by art enables the child to better unfold, show his / her creative potential. The teacher, in turn, individualizing art classes, must foresee more than one teaching method and tool and be creative himself / herself. All the more that the more techniques the child knows, the easier it is for the teacher to plan various topics (Becker-Textor 2001).

\section{Selection and use of art techniques, tools}

L. Marder (2010) points out that in order to develop preschool-age children's creativity, one cannot limit oneself to just usual art tools and traditional ways of using them, as the child becomes more involved in unusual, new processes. Methodological Recommendations for Preschool Education (2015) also propose to experiment in artistic activities as much as possible, take a closer look at the possibilities provided by various materials and techniques, and encourage children to diverse creative expression.

The study aimed to find out what kind of art techniques are most often used by teachers while educating children by art. The answers chosen by the respondents disclosed that organising art activities, most of the respondents prefer traditional art techniques: drawing (73.1 percent), moulding (54.9 percent), painting (50.5 percent), applique (44.5 percent), stamping (43.9 percent) and other techniques (42.9 percent). A share of research participants indicated that they never used frottage (26.9 percent), sand drawing (13.2 percent),

\footnotetext{
1 Individualization in this article is understood as a form of education, in which children's individual differences are taken into account in the educational process, and based on this, the educational methods, the curriculum are chosen.
} 
collage (9.9 percent) and monotype (9.3 percent) techniques. Such a choice of teachers could have been determined by the learners' age, since the use of traditional techniques and tools is simpler and easier while working with larger groups of learners. Meanwhile, less commonly used techniques are more time consuming, require more individual work. The research participants pointed out even more factors determining the choice of art techniques during activities. There are: children's wish and choice to work using one or another technique; children's age, application of well-known, tried out techniques; implementation of the curriculum, when the teacher takes into account the foreseen topics of the day, week, or month; the teacher's competence and ingenuity. Depending on the techniques, the tools are also selected. Nevertheless, children in the nursery need to be provided with possibilities to develop ideas, imagination, get acquainted with various art techniques. According to K. Cox (2009), education by art encompasses but is not limited to drawing, painting, and moulding. Young children should be interested by comprehensively good art experiences.

The teachers who participated in the study indicated the materials and tools used in art activities (Table 2).

Table 2. Materials, tools used in art activities

\begin{tabular}{|l|c|l|}
\hline \multicolumn{1}{|c|}{ Materials, tools used } & Percent & \multicolumn{1}{c|}{ More common examples } \\
\hline $\begin{array}{l}\text { Natural materials (dried leaves, } \\
\text { petals, small sticks, stones, clay, wax, } \\
\text { sand, seeds, charcoal, shells, etc.) }\end{array}$ & 45.6 percent & $\begin{array}{l}\text { "Drawing with sticks, feathers; moulding } \\
\text { from clay", "We use natural materials } \\
\text { (stones, dried petals, sawdust)", } \\
\text { "Applique from dried leaves". }\end{array}$ \\
\hline $\begin{array}{l}\text { Secondary materials (newspapers, } \\
\text { fabric scraps, pencil shavings, plastic } \\
\text { yoghurt pots, plastic bottles, bottle } \\
\text { caps, polyethylene, plastic straws, etc.) }\end{array}$ & 45.6 percent & $\begin{array}{l}\text { "We use straws for construction", } \\
\text { "Drawing on foam rubber, fabric", } \\
\text { "We collect plastic bottle caps, yoghurt } \\
\text { pots and use them in art". }\end{array}$ \\
\hline $\begin{array}{l}\text { Paper (crepe paper, paper for } \\
\text { journals, corrugated, wallpaper, } \\
\text { toilet paper, etc.) }\end{array}$ & 18.1 percent & $\begin{array}{l}\text { "We make clothes, caps from crepe } \\
\text { paper", "Various paper (paper for } \\
\text { journals, toilet paper)", "Drawing on } \\
\text { corrugated paper". }\end{array}$ \\
\hline $\begin{array}{l}\text { Food products (vegetables, } \\
\text { groats, pasta) }\end{array}$ & 13.7 percent & $\begin{array}{l}\text { "We use beetroot for stamping", "When } \\
\text { creating joint projects we use groats, } \\
\text { pasta". }\end{array}$ \\
\hline
\end{tabular}

To sum up, it can be stated that when organizing art activities, teachers choose traditional and non-traditional materials and tools. Such choice of teachers shows both their ability to organize art activities creatively and their ecological thinking. On the other hand, part of teachers point out that choosing secondary materials (or household waste), they "get out of a situation" when they lack standard, traditional materials or tools.

Non-traditional art activities offered by teachers to children are: drawing with fingers, palms (62.6 percent), drawing on snow (32.9 percent), drawing on glass (23.7 percent), drawing with sticks, toothpicks, feathers (18.7 percent), drawing with charcoal, the mass 
of sand, sawdust and glue (18.7 percent), glue splashing (18.1 percent), appliqués with pencil shavings ( 5 percent), magnet drawing (4 percent). Four teachers who took part in the research pointed out that art activity can be diversified by means of modern information technologies: "Children draw not only with pencils and felt-tips but also using tablets"; "Sometimes we create possibilities for children's artistic self-expression (drawing) at the interactive board." The examples presented demonstrate that children are introduced to various non-traditional art techniques, which develop both fine motor skills and children's creative abilities, promote self-expression.

To sum up, it can be stated that organising art activities, teachers chose quite different materials. Most often, these are natural materials, secondary materials. The said materials can be chosen for several reasons: it is simple to get the material (natural materials can be obtained during trips to nature; secondary materials can be supplied by parents); development of artistic and cognitive competencies; development of children's imagination, creativity, fantasy; broadening of children's knowledge about nature, the surrounding environment; awakening of sensitivity to beauty. Besides, children learn about unconventional ways of using traditional materials.

\section{Problems encountered during children's education by art}

Teachers involved in the research encountered various problems hindering the appropriate organization of art activities for preschoolers. The main ones pointed out are as follows: large groups of learners; lack of time; lack of tools or their poor quality; some children's reluctance to draw.

Teachers who took part in the research admit that the choice of art techniques is one of the factors determining children's successful creation and self-expression. Teachers indicated that they were trying to create conditions for children to try out different techniques, but it does not always depend on them. A share of respondents chose techniques, considering the tools and materials available in the group and pre-school education institution. Teachers admit that they face poor quality of the available tools for art expression and a lack of more diverse or unconventional tools: "often the administrative staff buys usual, inexpensive tools, and if you want something "more luxurious", unusual, it's the very educators' concern". One of the respondents states: "In general, we choose such tools that we have, for example, in the group we sort the second-rate waste, so we make quite a lot of artworks from them".

Another problem named by the respondents is children's reluctance to create and take part in art activities. Children want unconventional art activities, experiments, "some just don't want to draw, but want to work with kinetic sand, they willingly take up anything that is new, experiments: painting with gouache bags, painting on a mirror". A share of the respondents ( 7.7 percent) indicated that they worked with a large group of children, sometimes with a mixed age group, part (5.5 percent) acknowledged that they lacked time for longer classes. 


\section{Conclusions}

Art activities organized by the preschool education teacher help to develop preschoolers' artistic competency, while integration of art activities into other activity areas creates possibilities for the development of pre-schoolers' other competencies as well (cognitive, social, communication and health protection). From the teachers' standpoint, education by art is important for the progress of children's self-education, development of creativity, imagination and self-expression.

Planned and organized art activities also promote the very teacher's originality, selfexpression and creativity. The teacher must be prepared to individualize the curriculum, choose attractive, unconventional art techniques and tools for children, promoting their creativity. Assessing the learners' achievements in artistic expression and creativity areas, teachers take into account learners' experiences, emotions, feelings, acquired during the art process.

Problem areas of organising education by art named by teachers are large groups of learners, which determines that the process of individualization of education is more complicated, a share of children lack motivation, and there are problems of choosing art tools. On the other hand, children's motivation to art is promoted by children's non-restriction and free, spontaneous creation, using unconventional, everyday household tools. Just the very teachers' initiative and creativity are needed.

\section{Discussion}

The selected research strategy included the quantitative study, the results of which (teachers' attitude to the investigated problem and teachers' experience) were assessed by performing data calculation in percent and the qualitative content analysis (by analyzing answers to open-ended questions). From the standpoint of the authors of the research, deeper investigation of the analyzed problem could be performed by organising structured interviews or focus groups with teachers in the future. Exclusion of children as a group of respondents from the sample could be named as the limitation of the conducted research. It is important for preschool children that they should feel creative motivation as well as positive emotions arising during the creative process, which both show interest as a preliminary emotion and happiness or interpersonal sympathy, which can have a facilitating impact on the creative process. Further scientific studies could include the organization of an interview with children using a thematic drawing or another research method, conducting qualitative research on children's self-education by art. It is likely that such kind of study would enable to disclose more possibilities of children's education by art, find out children's expectations or what determines the lack of motivation to art. All the more that the authors of the research have experience organising qualitative research (conducted research included such methods as the analysis of children's activity products (drawings) in order to disclose the manifestations of children's creativity (Poneliene, Gumuliauskienè 
2008); the interview with the child using an unfinished thematic drawing (Juodaitytè, Ponelienè 2014).

\section{References}

Adomaitienė R. (2016), Puoselejjame vaiko saviraiška daile ar slopiname? "Žvirblių takas", 2.

Becker-Textor I. (2001), Kürybiškumas vaiku darželyje. Vilnius, Presvika.

Brazauskaitė A. (2004), Vaiku dailès terapinis aspektas. Vilnius, Gimtasis žodis.

Cox K. (2009), Fine Arts - Visual arts education. Georgia performance standards. Access through internet: http://www.docshok.com/uploads/Fine-arts-visual-gps-final1466578429.pdf.

Einarsdottira J., Dockettb S., Perry B. (2009), Making meaning: children's perspectives expressed through drawings. London, Routledge.

Eisner W.E. (2002). The Arts and the Creation of Mind. New Haven, Yale University Press.

Foster D.M., Beamer D.B., Atkinson D.T. and others (2013), Visual Arts Standards of Learning for Virginia Public Schools. Board of Education Commonwealth of Virginia. Access through internet: http://www.doe.virginia.gov/testing/sol/standards_docs/fine_arts/2013/visual_arts/ std_finearts_visualarts.pdf

Gronlund G. (2015), Individualizing Curriculum in Preschool and Kindergarten: Finding Delight in Each Child. Access through internet: http://www.isacs.org/uploads/file/\%231\%20Individualzing $\% 20$ Handouts.pdf

Hall E. (2009), Mixed messages: The role and value of drawing in early education. "International Journal of Early Years Education", 17(3).

Hille K., Evanschitzlky P., Bauer A. (2015), 3-6 metu vaiko raida: psichologijos pagrindai ikimokyklinio amžiaus vaiku ugdytojams. Vilnius, Tyto alba.

Ikimokyklinio amžiaus vaiku pasiekimu aprašas (2014). Vilnius, ŠMM Švietimo aprūpinimo centras.

Ikimokyklinio ugdymo metodinèse rekomendacijos (2015). Vilnius: ŠMM Švietimo aprūpinimo centras.

Juodaitytė A., Ponelienė R. (2014), Educational conditions for (self-)development of children's resistance to consumerism in the family. „Wychowanie w Rodzinie“, 2(10).

Kindler M.A. (2010), Art and art in early childhood: What can young children learn from "Art activities?" "International Art in Early Childhood Research Journal", 2(1). Access through internet: http://artinearlychildhood.org/artec/images/article/ARTEC_2010_Research_Journal_1_Article_1.pdf

Marder L. (2010), Spalvotas pasaulis. Vilnius, Presvika.

McClure M., Tarr P., Thompson C.M., Eckhoff, A. (2017), Defining quality in visual art education for young children: building on the position statement of the early childhood art educators. "Arts Education Policy Review", 118(3).

Ponelienė R., Gumuliauskienė A. (2008), Priešmokyklinio amžiaus vaiku kūrybiškumo apraiškos menineje veikloje (Expression of Creativity in Pre-School Age Children in Artistic Activities). "Jaunujjų mokslininkų darbai", 1(17). Access through internet: http://www.su.lt/images/leidiniai/JMD/2008_17/14_poneliene_gumuliauskiene.pdf

Ring K. (2001). Young children's drawing: the significance of the context. Access through internet: http://www.leeds.ac.uk/educol/documents/00001927.htm. 
Vecchi V. (2010), Art and Creativity in Reggio Emilia: Exploring the role and potential of ateliers in early childhood education. London and New York, Routledge.

Wright S. (2007), Young children's meaning making through drawing and "telling": Analogies to filmic textual features. "Australian Journal of Early Childhood”, 32(4).

Židonytė V. (2005), Ar mokyti vaikus dailès? "Žvirblių takas”, 1(59). 